Zabytkoznawstwo i Konserwatorstwo XLII, Toruń 2011

Arletta Tomaszewska

Alina Tomaszewska-Szewczyk

Zakład Konserwacji Elementów i Detali Architektonicznych UMK

\title{
Konsolidacja zniszczonej mechanicznie dekoracji emalierskiej na miedzi i jej stopach za pomocą żywic termoplastycznych
}

\section{Wprowadzenie}

Drzeprowadzone badania nad stanem zachowania kolekcji zabytków

1 z Muzeum Okręgowego w Toruniu oraz Muzeum Narodowego w Poznaniu, sporządzonych z miedzi i jej stopów oraz dekorowanych emalia w technice cloisonné, wykazały, że główna przyczyną ich destrukcji są zniszczenia mechaniczne. Powstałe uszkodzenia zakłócają estetykę odbioru, a niejednokrotnie przez zmianę pierwotnej geometrii następuje zachwianie stabilności niektórych obiektów. W efekcie tych zniszczeń w strukturze emalii oraz między nią a podłożem tworza się puste przestrzenie. Aby zapobiec dalszej destrukcji, należy wprowadzić środek, który wypełni te obszary. Przygotowano systematykę zniszczeń mechanicznych emalii. Ustalono kryteria, jakim mają odpowiadać środki do jej konsolidacji, oraz dopasowano metody ich aplikacji. Przebadano możliwości stosowania do tego zabiegu żywic termoplastycznych oraz podjęto próbę opracowania metodyki postępowania $z$ deformacjami. 
Podsumowując stan badań, można stwierdzić, że niewiele prac wnikliwie i obszernie porusza zagadnienia konsolidacji dekoracji emalierskiej na podłożu metalowym. Z pewnością daje obraz zmian, jakie zachodziły w praktykach konserwatorskich przez lata. Uwagę badaczy skupiły głównie zniszczenia korozyjne emalii. W związku z tym dążono do opracowania metod przeciwdziałania temu zjawisku.

Wczesne realizacje i propozycje postępowania konserwatorskiego miały na celu wymianę zniekształconego detalu, ponowne emaliowanie lub wklejanie wstawek z nowej emalii1. Od lat powojennych XX wieku zaczęła wzrastać świadomość potrzeby zachowania zniszczonej substancji zabytkowej. Pierwsze próby zabezpieczania dekoracji emalierskiej polegały na powierzchniowym pokrywaniu obiektu powłokami żywic naturalnych, które sukcesywnie były wypierane przez polimery syntetyczne. Początkowo wykorzystywano polioctan winylu ${ }^{2}$. Od lat 80 . środki konsolidujące - woski mikrokrystaliczne, żywice akrylowe, cykloheksanonowe, a także epoksydowe - zaczęto wprowadzać w spękania i rysy ${ }^{3}$. B. Langrebe stosował impregnacje próżniową przy ogrzewaniu promieniami podczerwonymi ${ }^{4}$. Pod koniec XX wieku do konsolidacji emalii zaczęto używać preparatów określanych nazwą ORMOCER (czyli organicznie modyfikowana ceramika): Glas-ORMOCER OR-G oraz Bronze-ORMOCER OR-B w kompozycjach z żywicą Paraloid B-72. Wprowadzano je za pomoca pędzla lub pipety w uszkodzone miejsca, częściowo także przez pokrywanie. Po upływie określonego czasu od zakończenia aplikacji nadmiar żywicy z powierzchni emalii usuwano wacikiem zwilżonym rozpuszczalnikiem ${ }^{5}$.

1 A. G. Chu, Oriental cloisonné and other enamels. A Guide to Collecting and Repairing, New York 1975; R. Richter, Die Festigung der Emailpreziosen im Grünen Gewölbe. Restaurierungsgeschichte, Diskussion Konservierungsmittel, Beispiele, „Restauro”, 2000, Nr. 6, s. $447-454$.

2 R. Richter, op. cit.; T. Drayman-Weisser, The Early Painted Enamels of Limoges in the Walters Art Museum: Historical Context and Observations on Past Treatments, „Journal of the American Institute for Conservation”, 2003, no. 42/2, s. 279-312.

3 R. Richter, op. cit.; T. Drayman-Weisser, op. cit.; W. Ślesiński, Konserwacja zabytkón sz̨tuki, t. 3: Rzemiosto artystyczne, Warszawa 1995, s. 137-138.

4 W. Ślesiński, op. cit., s. 138.

5 W. Müller, D. Kruschke, C. Köcher, M. Pilz, H. Römich, C. Troll, Welches Festigungsmittel eignet sich? Experimentelle Forschungen an der BAM und ISC, „Restauro”, 2000, Nr. 6, s. 442-445. 
Badanie stanu zachowania obiektów z kolekcji Muzeum Okręgowego w Toruniu, które poddano zabiegom naprawczym, pokazuje, że metoda powlekania powierzchniowo powłoka emalii, osłabionej wskutek czynników mechanicznych, nie zapewniała jej skutecznej ochrony. Preparat konsolidujący zapewne częściowo wypełnił spękania dekoracji, jednak nie nadał jej stabilności. Nie wytworzył siły przeciwstawnej naprężeniu, powstającemu pomiędzy podłożem i warstwą dekoracyjną. W tej sytuacji nawet nieznaczne oddziaływanie mechaniczne powoduje dalsze wykruszanie się emalii w miejscach, gdzie nie została osadzona na metalu. Naniesione powłoki wywołały zmianę połysku oraz barwy dekoracji, a więc powstała nowa wartość estetyczna. Zastosowany wosk mikrokrystaliczny w efekcie zmatowił emalię. Wskutek jego ślepnięcia na jej powierzchni pojawiły się nieestetyczne smugi. Z kolei werniks damarowy znacznie zwiększył połysk. Z czasem powłoka w wyniku procesów starzeniowych stała się krucha, pojawiły się spękania i złuszczenia.

Można założyć, że wprowadzenie preparatu konsolidującego miejscowo, w powstałe wolne przestrzenie, w obszarach występowania spękań oraz rozwarstwień, pozwoli na efektywniejszą stabilizację. Zabieg ten powinien również umożliwić, w pewnych granicach, usunięcie deformacji podłoża. Kolejną zaleta jest budowanie zabezpieczenia antykorozyjnego podłoża. Narastanie na nim produktów korozji nie będzie obniżać adhezji emalii do metalu.

\section{Systematyka zniszczeń mechanicznych emalii}

Zniszczenia mechaniczne badanej grupy zabytków były spowodowane przypadkowym uderzeniem, użytkowaniem oraz zmianą funkcji. Pogłębiały je wady technologiczne oraz korozja emalii i podłoża metalowego. Ich zasięg i charakter zależy przede wszystkim od rodzaju czynnika mechanicznego działającego na obiekt, a także od jego geometrii i przyjętych rozwiązań w układzie dekoracji. Można podzielić je na zniszczenia z odsłonięciem podłoża metalowego oraz bez jego odsłonięcia.

Do pierwszej grupy będą należeć odspojenia emalii. Każdej deformacji podłoża towarzyszy odspojenie powłoki. Szczególnie rozległe ubytki powstają na podłożach wykonanych z blachy miedzianej. Dochodzi na- 
wet do jego rozdarcia. Metalowe przegródki zatrzymuja proces odspajania, chroniąc dalsze komórki emalii. W przypadku znacznych deformacji często odspajają się wraz z emalią. Na obszarach objętych uszkodzeniem pozostają niekiedy czastki emalii. Pozbawiony emalii metal nie jest chroniony antykorozyjnie. Narastające produkty korozji powodują dodatkowe naprężenia, a rozszczelnienie powłoki na obszarach przylegających do odspojeń sprzyja rozwojowi korozji pod nią, co z czasem powoduje dalszą utratę jej przyczepności.

W grupie zniszczeń powstających bez odsłonięcia podłoża można wyróżnić rozwarstwienia oraz spękania emalii. Typowy przykład stanowią rozwarstwienia daszkowe. Sa to niewielkie rozwarstwienia, zauważalne głównie dzięki zmianie barwy. Występują najczęściej w bezpośrednim sąsiedztwie wyraźnie widocznych uszkodzeń emalii, ale również powstają w efekcie odpuszczania naprężeń, które wytwarzają się np. wskutek korozji metalowych przegródek. W wyniku działania czynnika mechanicznego może dojść do płatkowego rozwarstwienia się emalii, przy czym ulega ona częściowemu wykruszeniu. Tworzy się uszkodzenie o ostrych krawędziach, schodkowo opadających w głąb ubytku, przy którym powłoka jest silnie rozwarstwiona. Kolejnym rodzajem zniszczeń są spękania. Kierunek ich przebiegu zależy od charakterystyki działającego czynnika mechanicznego oraz geometrii obiektu. Gdy w momencie powstawania spękanie napotyka na drodze metalową przegródkę komórki, następuje przerwanie ciagłości biegu i w zależności od siły uderzenia zatrzymuje się lub może zmienić kierunek. Występują cztery podstawowe formy spękań w warstwie emalii: promieniste, podłużne, dookólne oraz siatkowe. Typy zniszczeń emalii przedstawiają il. 1-6.

\section{Cechy środka do konsolidacji emalii}

Przyjęto następujące kryterium wyboru środka do konsolidacji zniszczonej w sposób mechaniczny emalii:

- przezroczystość i bezbarwność (istotna cecha, gdy substancja błonotwórcza jest wprowadzana między emalię a emalię i stanowi swego rodzaju mikrouzupełnienie),

- dobra przyczepność do metalowego podłoża oraz emalii, 
- elastyczność (szczególnie gdy ma być zastosowana jako wzmocnienie osłabionej emalii w trakcie prostowania zdeformowanej formy),

- odporność na wodę,

- niepowodowanie korozji podłoża,

- odpowiednie cechy aplikacyjne (lepkość, łatwość w usuwaniu nadmiaru, stosowanie w temperaturze pokojowej).

Jedną z zasad konserwacji jest odwracalność zabiegu, którą ogranicza wprowadzenie substancji pod dekorację czy w strukturę emalii. Próby usunięcia środka konsolidującego z zastosowaniem rozpuszczalnika, poprzedzone momentem jego pęcznienia, a więc zwiększenia objętości, mogą doprowadzić do powiększenia się rozwarstwień.

\section{Cel i zakres badań}

Celem badań jest ustalenie metodyki postępowania ze zniszczonymi mechanicznie zabytkami dekorowanymi emaliami w zakresie konsolidacji warstwy dekoracyjnej oraz usuwania deformacji. Zostana przebadane polimery mogące pełnić funkcję połączenia klejowego w układach emalia-metal i emalia-emalia, które będa aplikowane w postaci roztworów tworzących błony po odparowaniu rozpuszczalnika. W badaniach wstępnych zostana ocenione cechy tych błon: wygląd zewnętrzny, odporność na zarysowanie, twardość względna, elastyczność, przyczepność do podłoża, porowatość, a także odporność na działanie wody. Na tej podstawie zostaną wyselekcjonowane środki do dalszych testów, mających na celu sprawdzenie, jaka jest odporność połączeń wykonanych za ich pomocą w układzie emalia-emalia oraz emalia-metal na działanie wody oraz środowiska $1 \%$ roztworu chlorku sodu. Badanie rozłożenia żywicy w zniszczonej strukturze emalii pomoże określić możliwości aplikacyjne tych środków.

Do analiz wytypowano szeroko stosowane w konserwacji środki produkcji Rohm \& Haas (Filadelfia, USA) o nazwie handlowej Paraloid. Opierając się na cechach podanych przez producenta, wybrano te, które wydaja się przydatne do wyznaczonego powyżej celu. Sa to Paraloidy o symbolach: A-10S, A-101, A-21, B-44, B-48N, B-67, B-72, B-99N, F-10, NAD-10V. Do badań włączono również środki używane do konsolidacji warstw malarskich na podłożach metalowych: Beva 371 (Gustav Berger, 
USA) oraz Plexisol P550 (Bresciani, Włochy). W tab. 1 zamieszczono opis środków wytypowanych do badań.

Tab. 1. Środki wytypowane do konsolidacji zniszczonej emalii

\begin{tabular}{|c|c|c|c|c|}
\hline Lp. & Nazwa żywicy & $\begin{array}{l}\text { Rodzaj polimeru/ } \\
\text { /kopolimeru }\end{array}$ & $\begin{array}{l}\text { Postać wyjściowa, } \\
\text { stężenie żywicy (\%) }\end{array}$ & $\begin{array}{l}\text { Kompozycja użyta w badaniach } \\
\text { stężenie (\%), rozpuszczalnik }\end{array}$ \\
\hline 1 & Paraloid A-10S & metakrylan metylu & $\begin{array}{l}30 \% \text { roztwór w octanie } \\
\text { 1-metoksy-2-propylu }\end{array}$ & $10 \%$, ksylen \\
\hline 2 & Paraloid A-101 & metakrylan metylu & $\begin{array}{l}40 \% \text { roztwór w ketonie } \\
\text { metylu i etylu }\end{array}$ & $10 \%$, ksylen \\
\hline 3 & Paraloid A-21 & metakrylan metylu & $\begin{array}{l}30 \% \text { roztwór w toluenie } \\
\text { i butanolu }\end{array}$ & $10 \%$, toluen \\
\hline 4 & Paraloid B-44 & $\begin{array}{l}\text { metakrylan metylu } \\
\text { akrylan etylu }\end{array}$ & $100 \%$ & $10 \%$, ksylen \\
\hline 5 & Paraloid B-48N & $\begin{array}{l}\text { metakrylan metylu } \\
\text { akrylanu butylu }\end{array}$ & $100 \%$ & $\begin{array}{l}\text { 10\%, toluen:butanol } \\
\text { w proporcji } 9: 1\end{array}$ \\
\hline 6 & Paraloid B-67 & metakrylan izobutylu & $100 \%$ & $10 \%$, ksylen \\
\hline 7 & Paraloid B-72 & $\begin{array}{l}\text { metakrylan etylu } \\
\text { akrylan metylu }\end{array}$ & $100 \%$ & $10 \%$, ksylen \\
\hline 8 & Paraloid B-99N & $\begin{array}{l}\text { metakrylan metylu } \\
\text { metakrylanu butylu }\end{array}$ & $100 \%$ & $10 \%$, ksylen \\
\hline 9 & Paraloid F-10 & metakrylan butylu & $\begin{array}{l}40 \% \text { roztwór w benzynie } \\
\text { lakowej i rozpuszczalniku } \\
\text { aromatycznym }(9: 1)\end{array}$ & $\begin{array}{l}10 \% \text {, ksylen } \\
5 \% \text {, butanol }\end{array}$ \\
\hline 10 & Paraloid NAD-10V & $\begin{array}{l}\text { akrylan metylu } \\
\text { metakrylan izobutylu }\end{array}$ & $\begin{array}{c}40 \% \text { roztwór } \\
\text { w benzynie lakowej }\end{array}$ & $10 \%$, ksylen \\
\hline 11 & Beva 371 & $\begin{array}{l}\text { octan winylowo-ety- } \\
\text { lowy, parafina, żywica } \\
\text { ketonowa }\end{array}$ & $\begin{array}{l}40 \% \text { roztwór w mieszaninie } \\
\text { rozpuszczalników } \\
\text { alifatycznych } \\
\text { i aromatycznych }(55 \%)\end{array}$ & $10 \%$, ksylen \\
\hline 12 & Plexisol P550 & metakrylan butylu & $\begin{array}{c}40 \% \text { roztwór } \\
\text { w benzynie lakowej }\end{array}$ & $10 \%$, ksylen \\
\hline
\end{tabular}

\section{Badania wstępne powłok}

\section{Metodyka}

Wykonano następujące badania w celu określenia właściwości błon:

- wygląd zewnętrzny - zestalone błony na płytkach szklanych obserwowano okiem nieuzbrojonym, uwzględniając ich połysk (zgodnie 
z normą ISO 2813), obecność zanieczyszczeń mechanicznych, pęcherzyków, zmarszczek, śladów duktu pędzla;

- odporność na zarysowanie zgodnie z normą ISO 15 184;

- twardość względna wahadłem Königa zgodnie z normą ISO 1522;

- elastyczność zgodnie z normą ISO 1519-2;

- przyczepność do podłoża zgodnie z normą ISO 2409 - do wyników badań dołączono zdjęcia mikroskopowe wykonane systemem Nikona;

- porowatość - płytkę stalową o wymiarach $100 \times 50 \mathrm{~mm}$ pokryto obustronnie badaną kompozycją i ułożono w szalce Petriego. Zalano roztworem $2 \%$ siarczanu (VI) miedzi (II) zakwaszonym kwasem siarkowym (VI). Po upływie 2 godzin płytki wyjęto z roztworu i przemyto woda bieżąca, osuszono bibułą filtracyjna. Określono liczbę i wielkość ognisk wydzielonej miedzi oraz ich rozmieszczenia;

- odporność na działanie wody - płytkę szklaną o wymiarach $100 \times$ $\times 50 \mathrm{~mm}$ zważono z dokładnością do 0,002 g. Następnie pokryto dwustronnie badaną kompozycją i zważono ponownie, zanurzono w wodzie destylowanej na 24 godziny. Po wyjęciu osuszono bibuła filtracyjna i zważono. Procentowy przyrost masy powłoki w stosunku do jej masy pierwotnej oblicza się ze wzoru:

$\mathrm{P}=\left[\left(\mathrm{m}_{3}-\mathrm{m}_{2}\right) /\left(\mathrm{m}_{2}-\mathrm{m}_{1}\right)\right] \cdot 100 \%$, gdzie:

$\mathrm{m}_{1}$ - masa płytki $(\mathrm{g})$, $\mathrm{m}_{2}$ - masa płytki z błona $(\mathrm{g})$, $\mathrm{m}_{3}$ - masa płytki $\mathrm{z}$ błona po wyjęciu z wody (po spęcznieniu) (g);

- lepkość - pomiaru lepkości dokonano na wiskozymetrze Höpplera. Gęstość badanych roztworów wyznaczono na wadze Mohra-Westphala. 


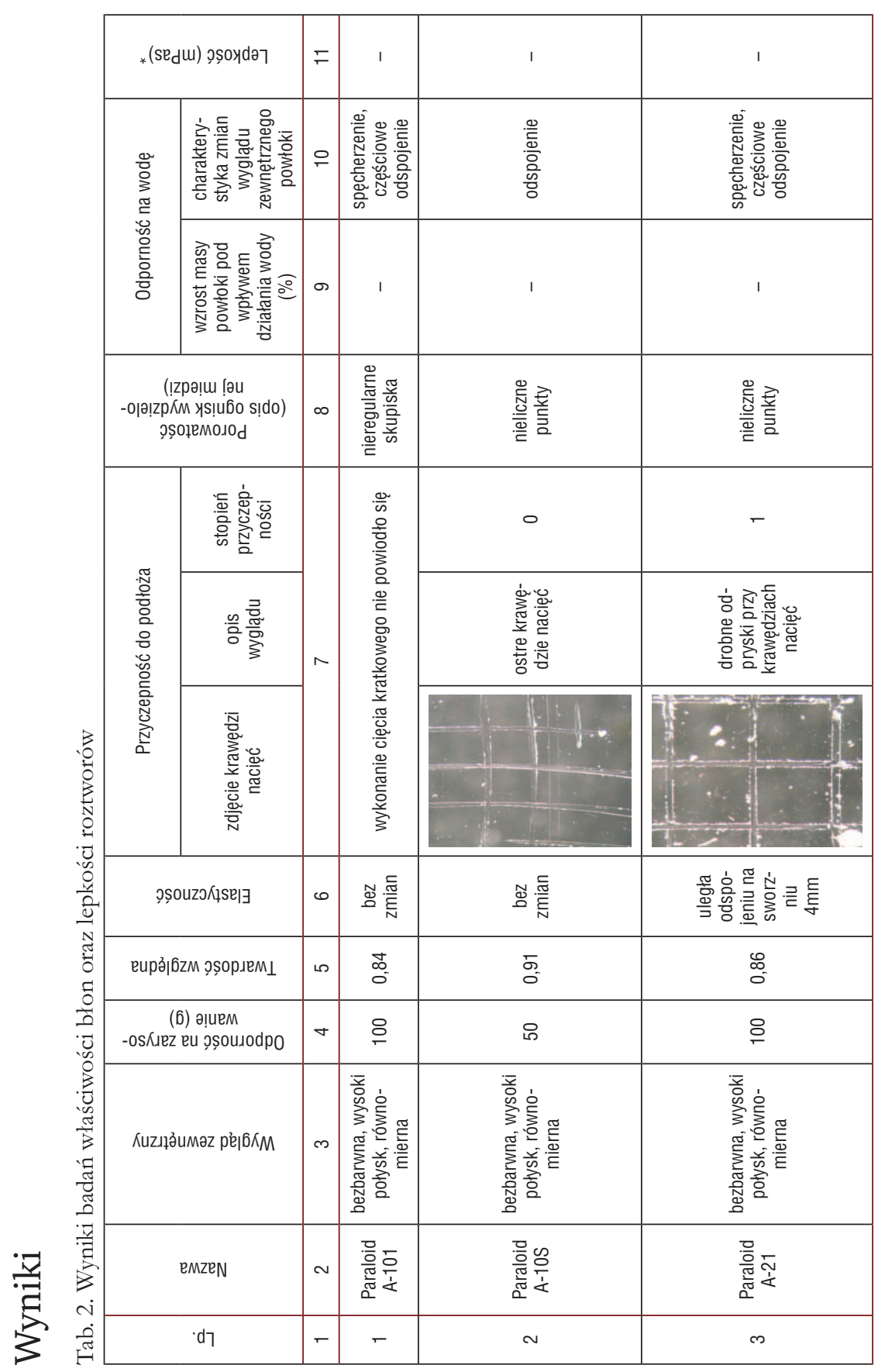




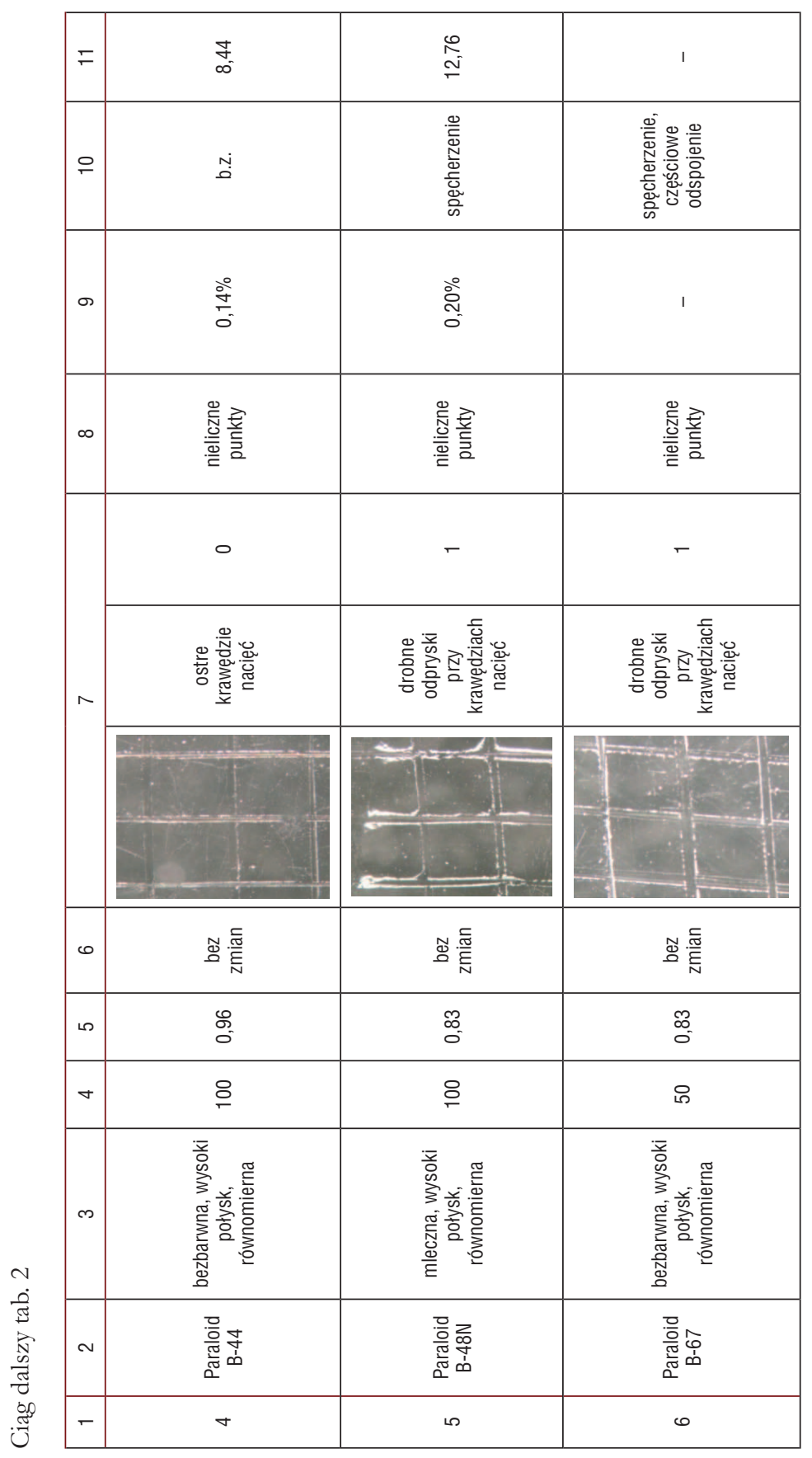




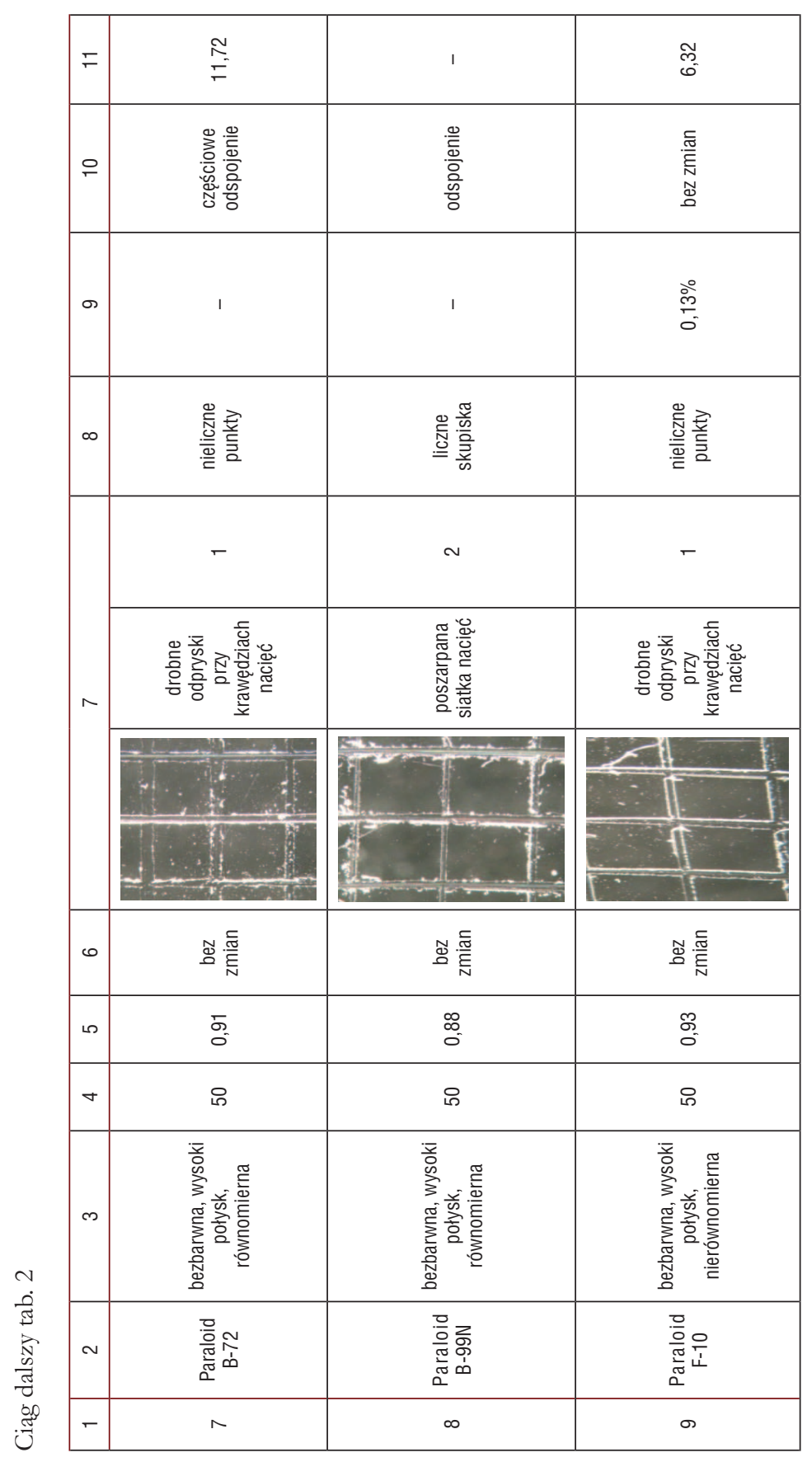




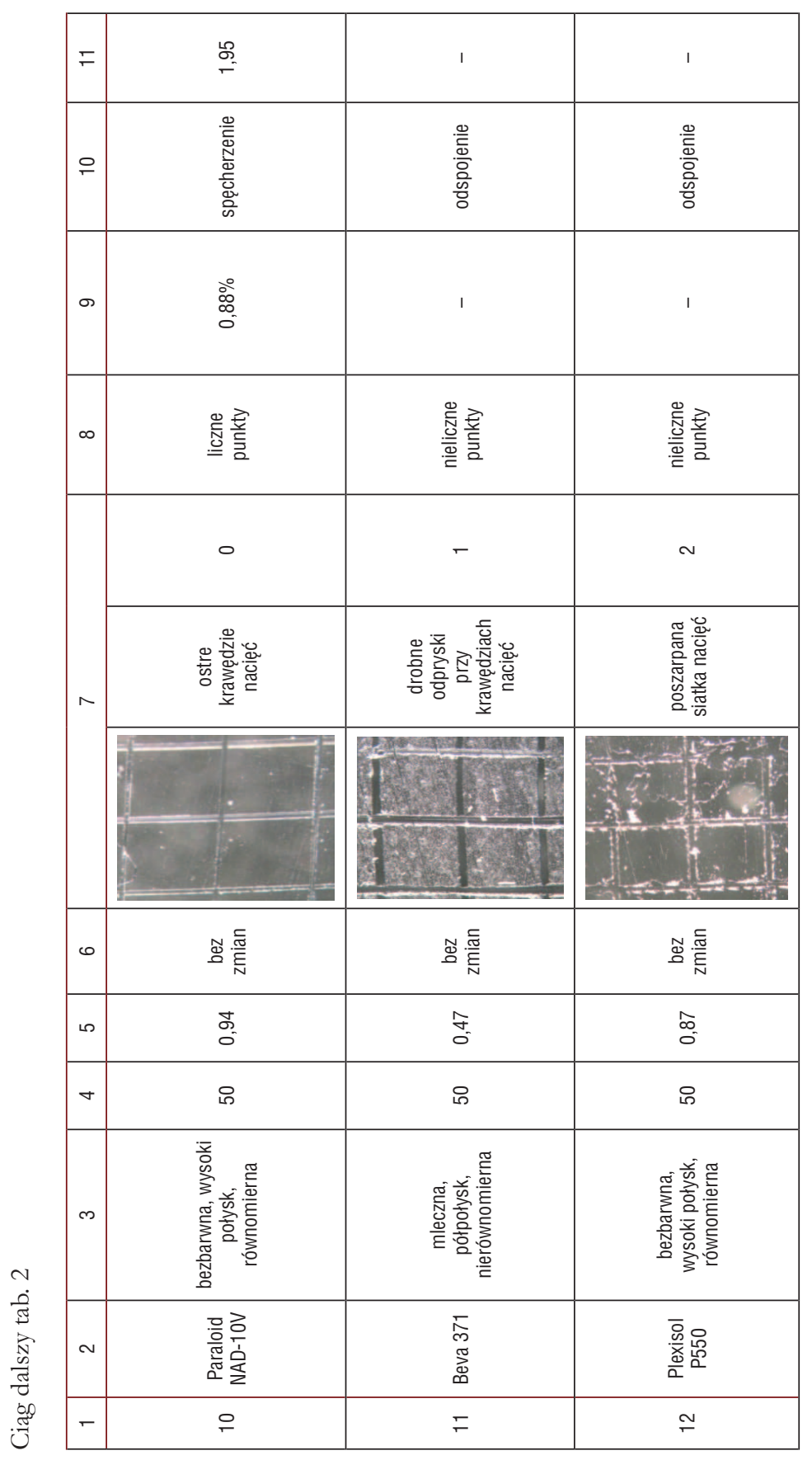




\section{Wnioski}

Większość badanych kompozycji tworzy błony bezbarwne, równomierne i o wysokim połysku. Wyjątek stanowią: Paraloid B-48N, którego błona zawiera nierozpuszczone części polimeru, Paraloid F-10, który rozkłada się nierównomiernie, oraz Beva 371 - tworzy błony mleczne, półpołyskliwe. Błony Paraloidów o symbolach: A-101, A-21, B-44, B-48N wykazały najwyższą odporność na zarysowanie. Paraloid B-44 wypadł najlepiej w badaniu twardości względnej, nieco niższe wartości osiagnęły polimery pozostałych Paraloidów oraz Plexisol P550. Natomiast wynik, jaki osiagnęła Beva 371, jest o połowę gorszy od najlepszego. Badane błony, poza Paraloidem A-21, maja zbliżona elastyczność. Natomiast ich przyczepność jest zróżnicowana. Najlepszą wykazują Paraloidy: A-10S, B-44, NAD-10V, a najmniejszą Paraloid B-99N oraz Plexisol P550. W wyniku badania, sprawdzającego porowatość utworzonych błon, stwierdzono, że Paraloid B-44 odznacza się najmniejszą porowatością. Najbardziej porowate błony tworza: Paraloid A-101, Paraloid B-99N, Plexisol P550. Badanie odporności błon na działanie wody dowiodło, iż część z nich jest nieodporna i uległa zniszczeniu, odspajając się od płytki szklanej w trakcie testu. Zaczynając od najbardziej odpornych, polimery można uszeregować następująco: Paraloid F-10, Paraloid B-44, Paraloid NAD-10V, Paraloid B-48N. Najwyższą lepkością charakteryzuje się roztwór Paraloidu B-48N, następnie Paraloidu B-44 i F-10, natomiast znacznie mniejszą lepkość wykazuje roztwór Paraloidu NAD-10V. Do dalszych badań wybrano Paraloid B-44 oraz F-10, ponieważ spośród badanych środków mają one najwyższa przydatność do zabiegu konsolidacji emalii. 


\section{Badanie odporności połączenia w układach emalia-emalia oraz emalia-metal na czynniki korozyjne - wodę i chlorek sodu}

\section{Metodyka}

Za pomoca 10\% roztworu Paraloidu B-44 oraz F-10 spojono odłamki emalii z miedzią oraz ze sobą. Następnie próbki zanurzono w wodzie na 60 godzin. Wykonano próbki z blachy miedzianej, która pokryto powłoka emalierska. Emalię zniszczono mechanicznie. Powstałe spękania podklejono badanymi roztworami. Następnie próbki zanurzono w 1\% roztworze chlorku sodu na 24 godziny. Po wyjęciu z roztworu przechowywano je przez 60 dób w środowisku o 100\% wilgotności względnej.

\section{Wyniki}

Tab. 3. Badanie wpływu środowiska wody na trwałość połączeń emalia-miedź i emalia-emalia oraz chlorku sodu na skonsolidowaną powłokę emalierską

\begin{tabular}{|c|c|c|c|c|}
\hline \multirow{2}{*}{ Lp. } & \multirow{2}{*}{ Środek } & \multicolumn{2}{|c|}{$\begin{array}{c}\text { Zmiany zachodzące pod wpływem } \\
\text { wody na połączenia }\end{array}$} & \multirow{2}{*}{$\begin{array}{l}\text { Zmiany zachodzące } \\
\text { pod wpływem chlorku sodu }\end{array}$} \\
\hline & & emalia-miedź & emalia-emalia & \\
\hline 1 & Paraloid B-44 & $\begin{array}{l}\text { po } 45 \text { godz. } \\
\text { odspojenie }\end{array}$ & $\begin{array}{l}\text { po } 40 \text { godz. } \\
\text { odspojenie }\end{array}$ & $\begin{array}{l}\text { w } 30 \text { dobie pojawiły się ogniska korozyjne } \\
\text { wielkości punktów, a w } 40 \text { dobie zaczełły } \\
\text { odspajać się drobne fragmenty emalii }\end{array}$ \\
\hline 2 & Paraloid F-10 & $\begin{array}{l}\text { po } 60 \text { godz. } \\
\text { bez zmian }\end{array}$ & $\begin{array}{l}\text { po } 60 \text { godz. } \\
\text { bez zmian }\end{array}$ & $\begin{array}{l}\text { w } 20 \text { dobie pojawiły się ogniska korozyjne } \\
\text { wielkości punktów, brak odspojeń emalii }\end{array}$ \\
\hline
\end{tabular}

\section{Wnioski}

Trwałość połączeń Paraloidu F-10 jest wyższa niż Paraloidu B-44, ale drugi z polimerów dłużej chroni miedzianą powierzchnię przed działaniem chlorku sodu. Efekt zespolenia emalii z emalią jest słabszy niż emalii z miedzią, na co wskazują wyniki badań z użyciem Paraloidu B-44. 


\section{Opracowanie metodyki przeprowadzania zabiegu konsolidacji}

\section{Metodyka}

Próbki miedziane z powłoką emalierską wyginano pod kątem $10^{\circ}$, a następnie prostowano. Uzyskano w ten sposób siatkę drobnych spękań. Następnie przeprowadzono zabieg konsolidacji. 10\% roztwór Paraloidu F-10 z 1\% dodatkiem luminoforu Gryf TBF-1 (Zachem, Polska) aplikowano bezpośrednio za pomoca pędzla oraz przez warstwę bibułki japońskiej. Dobę po zabiegu żywicę z powierzchni emalii usuwano, stosując różne materiały nasycone acetonem, tj. watę bawełniana, gazę higroskopijna, mikrofibrę. Po odparowaniu rozpuszczalnika w świetle UV badano efekty przesycenia spękań. Odspajano również mechanicznie emalię i sprawdzano, czy roztwór spenetrował zniszczoną strukturę do podłoża.

\section{Wyniki}

Wyniki badań zaprezentowano w tab. 4 na zdjęciach wykonanych w świetle UV.

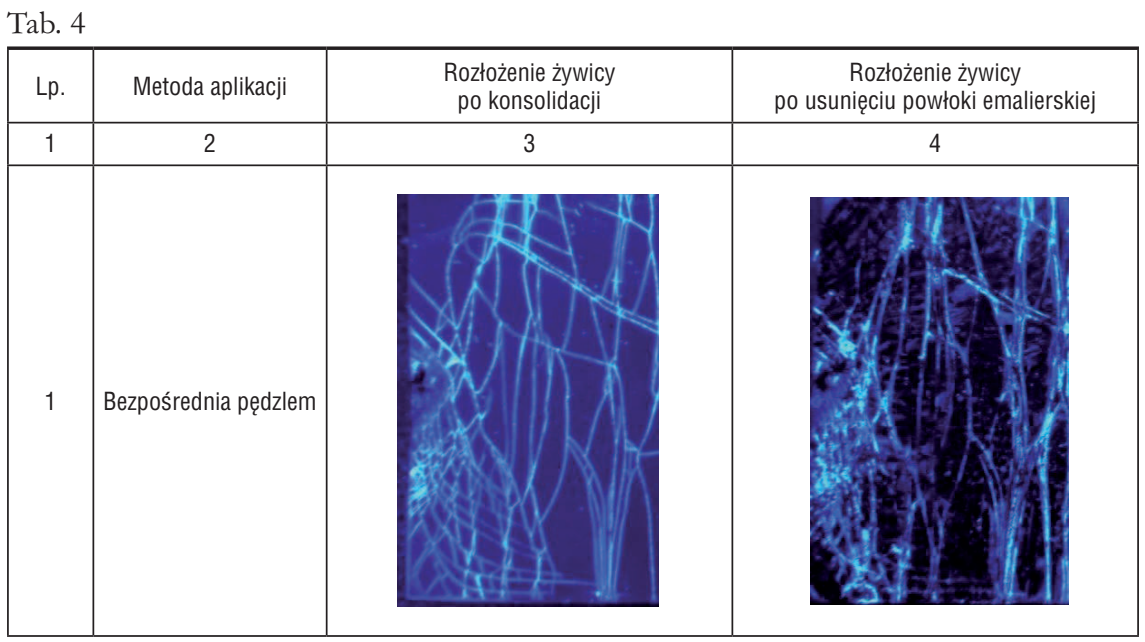


Ciag dalszy tab. 4

\begin{tabular}{|c|c|c|c|}
\hline 1 & 2 & 3 & \\
\hline 2 & $\begin{array}{c}\text { Pedzlem przez } \\
\text { warstwé bibutki } \\
\text { japońskiej }\end{array}$ \\
\hline
\end{tabular}

\section{Wnioski}

W wyniku badania ustalono, że analizowane metody aplikacji środka są równie efektywne. Jednakże nasycanie przez bibułkę japońską jest wskazane ze względu na dbałość o substancję zabytkową. W miejscach, gdzie emalia uległa silnemu rozluźnieniu, nośnik ten zabezpieczył ją przed wyrywaniem luźnych odłamków. Możliwe jest całkowite usunięcie żywicy z powierzchni emalii przy użyciu materiałów nasyconych rozpuszczalnikiem. Do tego celu najlepiej stosować mikrofibrę o drobnym splocie, gdyż jej włókna nie wczepiają się w nierówności powierzchni, co ogranicza możliwość przypadkowego wyrwania fragmentu emalii.

\section{Opracowanie metodyki zabezpieczenia emalii przy usuwaniu deformacji podłoża}

\section{Metodyka}

Miedziane próbki z powłoką emalii o grubości od 0,5 do 0,7 mm zniszczono mechanicznie w taki sposób, aby uzyskać deformację podłoża w stopniu nieznacznym oraz dużym, z całkowitym i częściowym odspojeniem emalii. Przeprowadzono zabieg usuwania deformacji, zabezpieczając emalię na kilka sposobów: 
a) emalię zabezpieczono bibułka japońska,

b) emalię skonsolidowano i zabezpieczono bibułka japońska,

c) emalię zabezpieczono bibułką japońską, a następnie zaraz po prostowaniu skonsolidowano ją i usunięto zabezpieczenie,

f) emalię skonsolidowano, zabezpieczono bibułką japońską, a następnie po prostowaniu ponownie nasycano.

Jako środek konsolidujący zastosowano 10\% roztwory żywic: 10\% Paraloid B-44 oraz F-10 w ksylenie.

\section{Wyniki}

Tab. 5. Efekty zabezpieczania emalii w celu usunięcia deformacji

\begin{tabular}{|c|c|c|c|c|c|}
\hline Lp. & Wariant & Preparat & $\begin{array}{c}\text { Stan przed } \\
\text { usunięciem deformacji }\end{array}$ & $\begin{array}{l}\text { Stan po usunięciu } \\
\text { deformacji }\end{array}$ & $\begin{array}{l}\text { Efektywność } \\
\text { metody }\end{array}$ \\
\hline 1 & 2 & 3 & 4 & 5 & 6 \\
\hline 1 & & $\begin{array}{c}\text { Paraloid } \\
\text { B-44 }\end{array}$ & & & $\begin{array}{l}\text { czesściowe } \\
\text { odspojenie } \\
\text { emalii }\end{array}$ \\
\hline 2 & & $\begin{array}{l}\text { Paraloid } \\
\text { F-10 }\end{array}$ & & & $\begin{array}{l}\text { czesściowe } \\
\text { odspojenie } \\
\text { emalii }\end{array}$ \\
\hline 3 & & $\begin{array}{c}\text { Paraloid } \\
\text { B-44 }\end{array}$ & & & $\begin{array}{l}\text { czesściowe } \\
\text { odspojenie } \\
\text { emalii }\end{array}$ \\
\hline 4 & & $\begin{array}{c}\text { Paraloid } \\
\text { F-10 }\end{array}$ & & & $\begin{array}{l}\text { częściowe } \\
\text { odspojenie }\end{array}$ \\
\hline
\end{tabular}


Ciag dalszy tab. 5

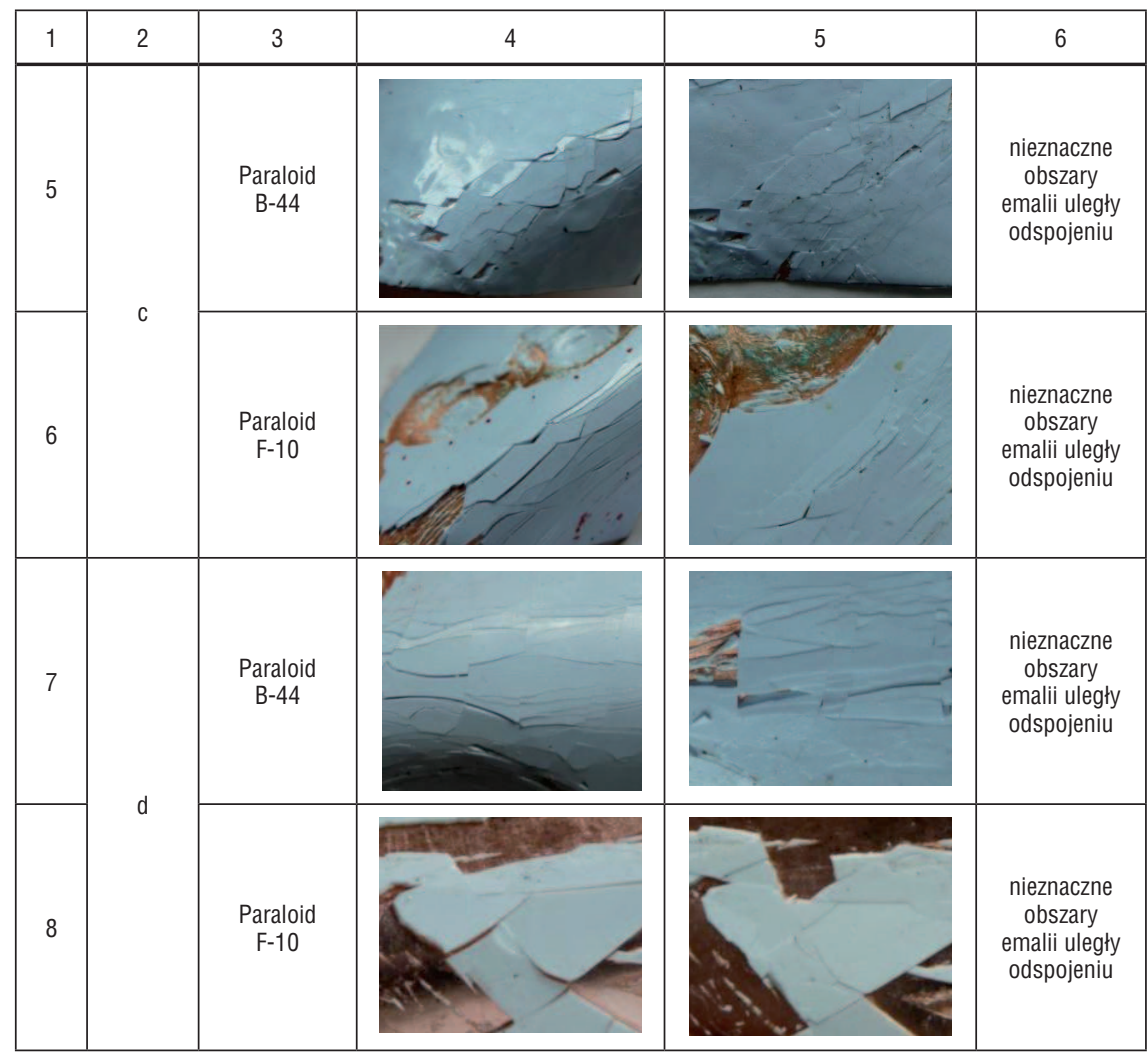

\section{Wnioski}

Podklejenie odspojonej emalii roztworami żywic Paraloid B-44 i F-10 oraz dodatkowe zabezpieczenie, wykonane za pomocą bibułki japońskiej przed usunięciem zniekształcenia podłoża, ograniczaja jej utratę w trakcie przeprowadzania tego zabiegu. Następnie należy dokonać ponownej aplikacji środka. Sam proces usuwania deformacji musi przebiegać bardzo ostrożnie, ponieważ zarówno w emalii, jak i między emalia a metalem istnieją silne naprężenia. W przypadku odwracania znacznie zniekształconych podłoży pewna część emalii może ulec odspojeniu. Nie stwierdzono różnicy między zastosowanymi środkami. 


\section{Podsumowanie}

Przegląd literatury przedmiotu, a następnie przeprowadzone badania stanu zachowania obiektów zdobionych emalią w technice cloisonné z kolekcji Muzeum Okręgowego w Toruniu oraz Muzeum Narodowego w Poznaniu pozwoliły na określenie pola badawczego. Stwierdzono, że poważnym, niezbadanym zagadnieniem konserwatorskim jest konserwacja zniszczonej mechanicznie dekoracji emalierskiej, której często towarzyszy deformacja metalowego podłoża.

Wprowadzono następujący podział zniszczeń mechanicznych: z odsłonięciem podłoża - odspojenia, bez odsłonięcia podłoża - rozwarstwienia oraz spękania.

$\mathrm{Na}$ podstawie badań można stwierdzić, że skuteczną metodą zapobiegania dalszym niekorzystnym zmianom jest przeprowadzenie zabiegu konsolidacji. Polega on na aplikacji preparatu w zniszczoną strukturę emalii, który przynajmniej częściowo wypełni puste przestrzenie powstałe wskutek szkodliwego działania czynnika mechanicznego.

Do zabiegu konsolidacji wybrano środki z grupy żywic termoplastycznych. Po przeprowadzeniu badań wstępnych z grupy 12 produktów handlowych wytypowano dwa: Paraloid B-44 oraz Paraloid F-10.

Do podklejania spękań oraz rozwarstwień można użyć roztworów żywicy Paraloid F-10. Jednak w celu pełnego zabezpieczenia antykorozyjnego podłoża należy wykonać końcowe nasycanie, stosując roztwór żywicy Paraloid B-44.

Dokonując aplikacji w obszarach emalii silnie zniszczonej, a tym samym o osłabionej adhezji, bezpieczną metoda jest nasycanie przez bibułkę japońska. Uchroni ona emalię przed ewentualnym wyrwaniem drobin substancji zabytkowej przez bezpośrednie działanie pędzlem.

W wyniku przeprowadzonych doświadczeń ustalono, że w przypadku obiektów o zdeformowanym podłożu bezpiecznie można przywracać oryginalną formę jedynie przy niewielkich jej odkształceniach. Przed tym zabiegiem należy wprowadzić roztwór żywicy Paraloid F-10 w zniszczoną strukturę emalii, po czym zabezpieczyć jej powierzchnię bibułką japońską przyklejoną tym samym roztworem żywicy. Kolejna aplikacja powinna nastapić zaraz po zabiegu usuwania deformacji. Potem trzeba usunąć bi- 
bułkę i wprowadzić roztwór żywicy Paraloid B-44. W przypadku dużych deformacji zabieg prostowania zawsze wiąże się z utratą substancji zabytkowej.

Po aplikacji preparatów należy usunąć żywicę z powierzchni emalii za pomocą mikrofibry zwilżonej acetonem.

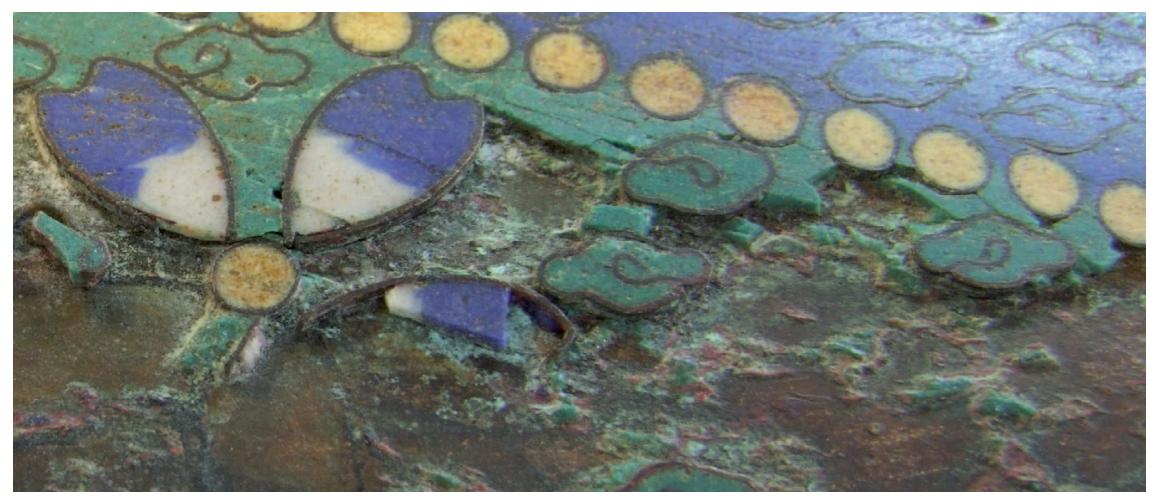

Il. 1. Odspojenie emalii (wszystkie zdjęcia zamieszczone w artykule wykonały autorki)

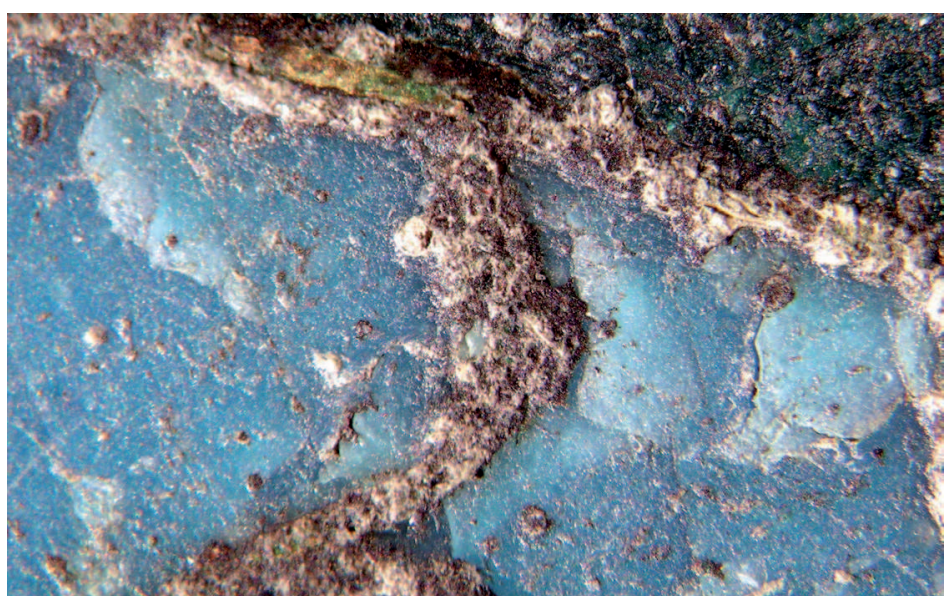

Il. 2. Rozwarstwienie emalii: daszkowe i płatkowe 


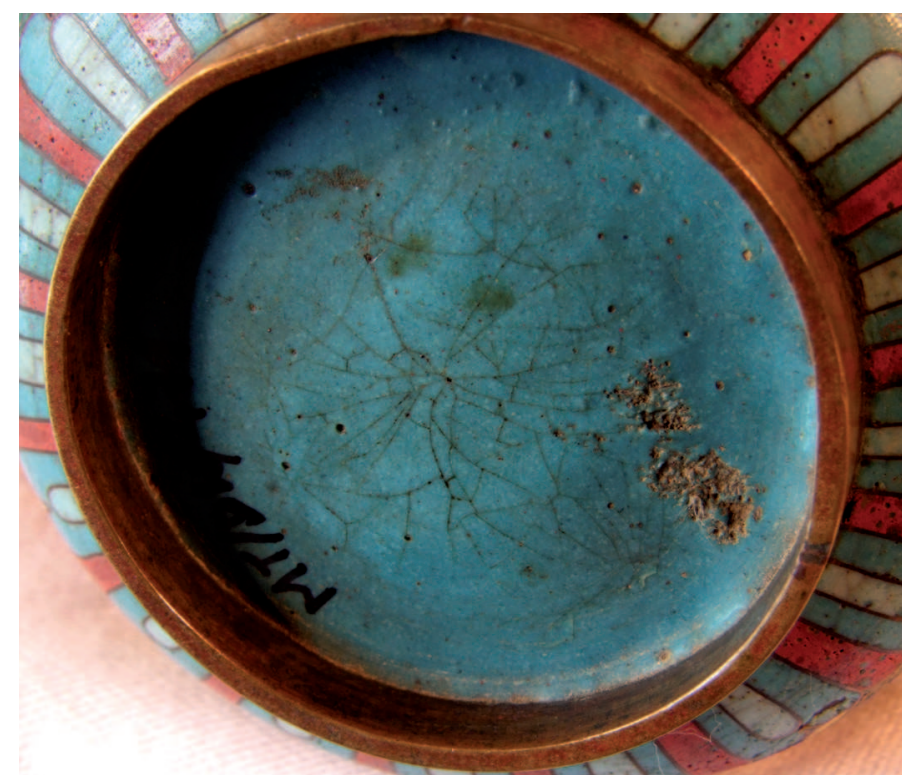

Il. 3. Spękanie promieniste emalii

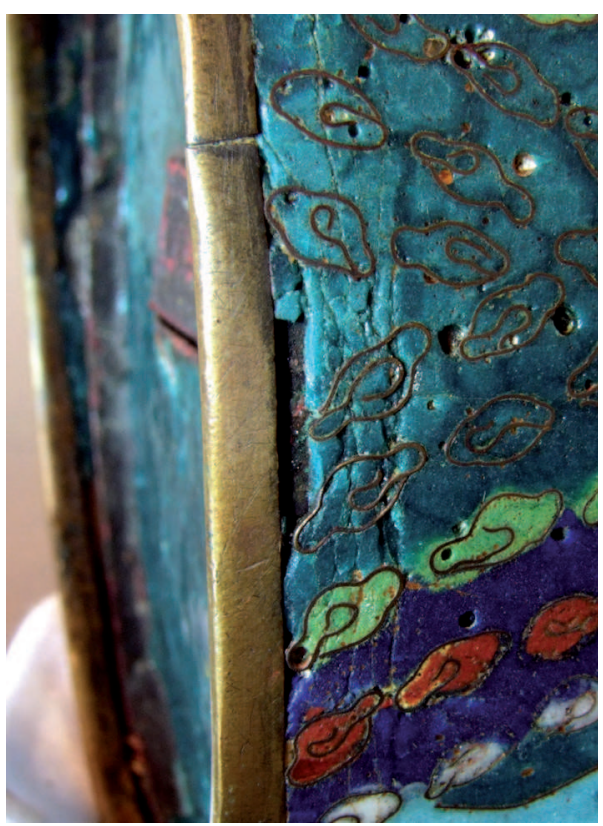

Il. 4. Spękanie podłużne emalii 


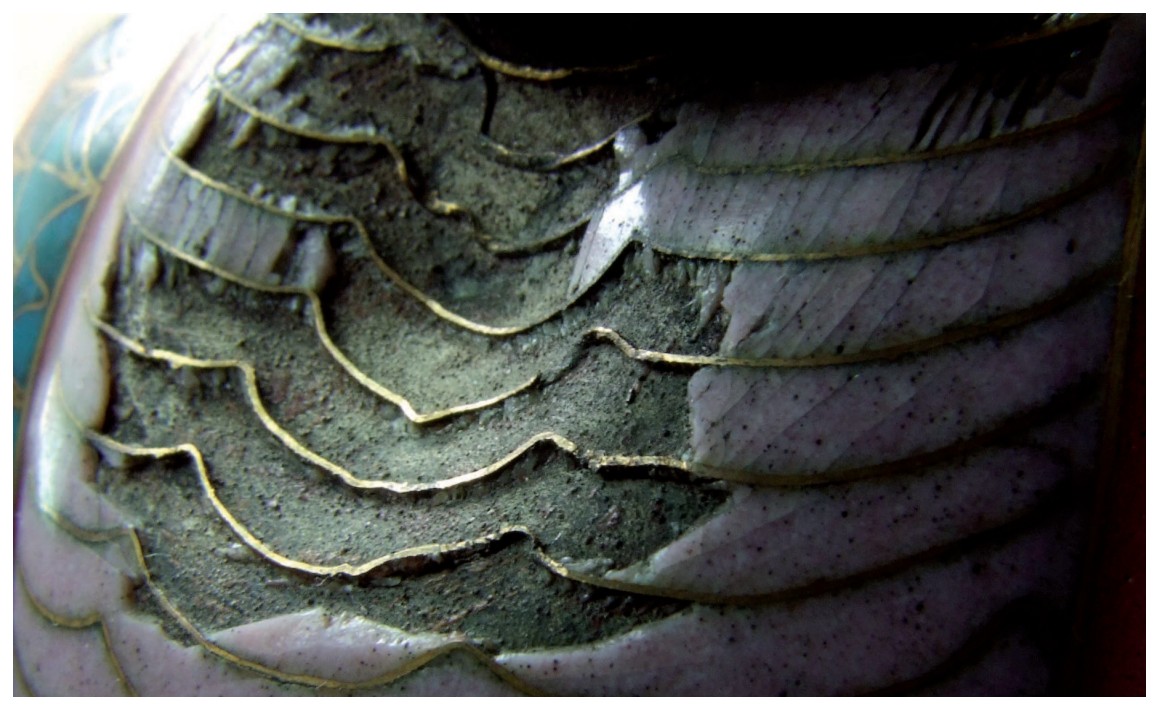

Il. 5. Spękanie dookólne emalii

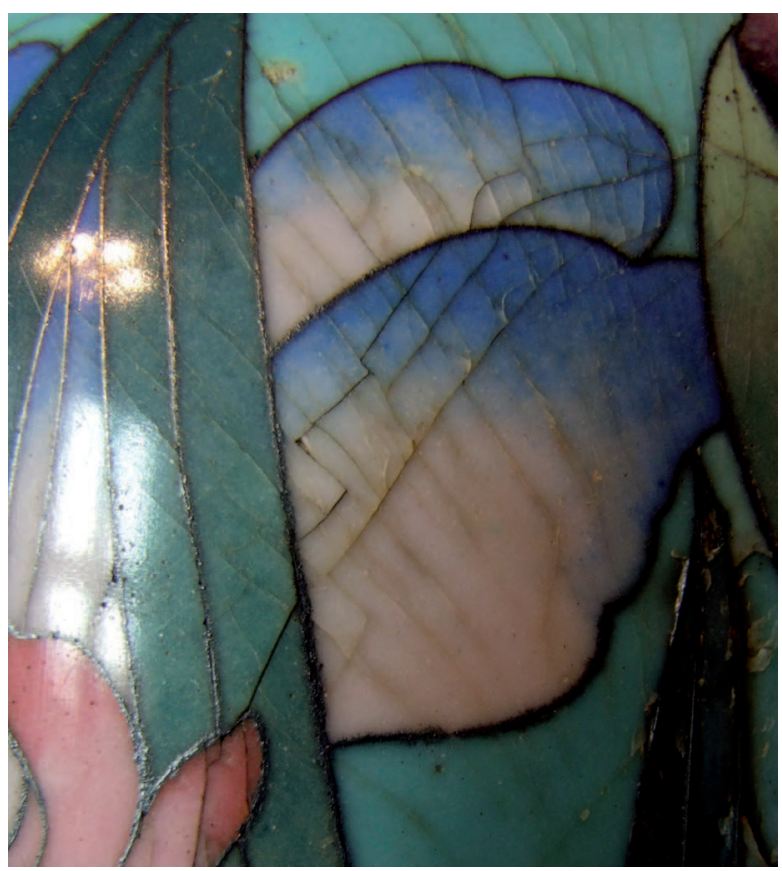

Il. 6. Spękanie siatkowe emalii 


\section{Summary}

\section{The consolidation of mechanically destroyed enamel decoration on copper and its alloys}

The objects of study were metal artefacts decorated with enamel. It was established that the main reason of destruction was mechanical damage that caused cracking and loosening of the enamel, and - in extreme cases - shape deformation and losses in the decoration layer. The main problem to be solved was the choice of methods and means for the consolidation of the exfoliated enamel as well as for setting it on the metal. Moreover, a method had to be established for dealing with shape deformation. A typology of damages was developed, so that criteria might be established by which to choose means of consolidation for mechanically destroyed enamel. On the basis of the research, a methodology of further proceedings was proposed, involving preparations fulfilling the main postulates.

The object of study was a group of 60 objects made of copper and its alloys and decorated with enamel. These were Chinese and Japanese artefacts from the Regional Museum in Torun and the National Museum in Poznań, dated from the $17^{\text {th }}$ century to the early $20^{\text {th }}$ century. The decorative techniques included cloisonné, champlevé and painted enamel.

The following typology of mechanical damages was developed, based on the state of the enamelled objects:

1. with the metal ground exposed:

- exfoliation;

2. with the metal ground unexposed:

- delamination: blistering, with partial exfoliation,

- cracking: longitudinal, radial, circular, reticular.

The main causes of damage were use, shape deformation, technological faults and corrosion of the metal surface.

The following criteria were taken into account for selecting a means of consolidation for mechanically damaged enamel:

- transparency and colourlessness,

- good adhesiveness to metal surfaces and enamel,

- elasticity (especially if an enamel layer is to be strengthened while removing shape deformation), 
- water-resistance,

- lack of corrosive influence,

- easy applicability: viscosity, easy excess removal, room temperature applicability.

The preparations selected for further study by the above criteria included acrylic resins popular in conservation (Paraloid A-10S, A-101, A-21, B-44, B-48N, B-67, B-72, B-99N, F-10, NAD-10V) and other thermoplastic resins used for paint layer consolidation on metal surfaces (Beva 371, Plexisol P550).

Preliminary assessments of such factors as the preparations' viscosity, elasticity, relative hardness, and water-resistance, made it possible to select three thermoplastic resins for further tests: Paraloid B-44 and Paraloid F-10.

Further experiments were conducted on sheet copper samples decorated with enamel. The samples were mechanically damaged, and the cracks, delaminations and exfoliations of the enamel layer were treated with the preparations in question. Luminophores were admixed to the preparations to monitor their penetration and distribution in the layer under UV light. Further tests examined the preparations' adhesiveness to the ground and the enamel under prolonged exposure to water; the anti-corrosive protection they offered to the metal; and their influence on shape deformation removal processes.

On the basis of the research, preparations were selected for the treatment of mechanically damaged enamel, their choice dependent on the type of damage. A methodology was proposed for excess preparation removal. Safe methods of object preparation for shape distortion removal were established, as well as methods of proceeding in cases where the original shape cannot be restored. Several badly damaged items then underwent conservation. 